\title{
A global model study of the impact of land-use change in Borneo on atmospheric composition
}

\author{
N. J. Warwick ${ }^{1,2}$, A. T. Archibald ${ }^{1,2}$, K. Ashworth ${ }^{3,}{ }^{*}$, J. Dorsey ${ }^{1,4}$, P. M. Edwards ${ }^{5}$, D. E. Heard ${ }^{1,6}$, B. Langford ${ }^{7}$, \\ J. Lee ${ }^{1,8}$, P. K. Misztal ${ }^{7,9,{ }^{* *}}$, L. K. Whalley ${ }^{1,6}$, and J. A. Pyle , $^{1,2}$ \\ ${ }^{1}$ National Centre for Atmospheric Science, NCAS, UK \\ ${ }^{2}$ Department of Chemistry, University of Cambridge, Lensfield Road, Cambridge, CB2 1EW, UK \\ ${ }^{3}$ Lancaster Environment Centre, Lancaster University, Lancaster, LA1 4YQ, UK \\ ${ }^{4}$ School of Earth, Atmospheric and Environmental Sciences, University of Manchester, Manchester, M13 3PL, UK \\ ${ }^{5}$ ESRL, National Oceanic and Atmospheric Administration, 325 Broadway, Boulder, CO 80305-3328, USA \\ ${ }^{6}$ School of Chemistry, University of Leeds, Woodhouse Lane, Leeds, LS2 9JT, UK \\ ${ }^{7}$ Centre for Ecology and Hydrology, Penicuik, EH26 OQB, UK \\ ${ }^{8}$ Department of Chemistry, University of York, Heslington, UK \\ ${ }^{9}$ Department of Chemistry, University of Edinburgh, Edinburgh, UK \\ *now at: KIT, Institute of Meteorology and Climate Research-Atmospheric Environmental Research, Kreuzeckbahn Str. 19, \\ 82467 Garmisch-Partenkirchen, Germany \\ ** now at: Deparment of Environmental Science, Policy and Management, University of California, Berkerley, CA 94720, \\ USA
}

Correspondence to: N. J. Warwick (nicola.warwick@atm.ch.cam.ac.uk)

Received: 19 December 2012 - Published in Atmos. Chem. Phys. Discuss.: 20 March 2013

Revised: 25 July 2013 - Accepted: 26 July 2013 - Published: 16 September 2013

\begin{abstract}
In this study, a high resolution version of the Cambridge p-TOMCAT chemical transport model is used, along with measurement data from the 2008 NERC-funded Oxidant and Particle Photochemical Processes (OP3) project, to examine the potential impact of the expansion of oil palm in Borneo on atmospheric composition. Several model emission scenarios are run for the OP3 measurement period, incorporating emissions from both global datasets and local flux measurements. Using the OP3 observed isoprene fluxes and $\mathrm{OH}$ recycling chemistry in p-TOMCAT substantially improves the comparison between modelled and observed isoprene and $\mathrm{OH}$ concentrations relative to using MEGAN isoprene emissions without $\mathrm{OH}$ recycling. However, a similar improvement was also achieved without using $\mathrm{HO}_{\mathrm{x}}$ recycling, by fixing boundary layer isoprene concentrations over Borneo to follow the OP3 observations. An extreme hypothetical future scenario, in which all of Borneo is converted to oil palm plantation, assessed the sensitivity of the model to changes in isoprene and $\mathrm{NO}_{\mathrm{x}}$ emissions associated with land-use change. This scenario suggested a $70 \%$ upper limit
\end{abstract}

on surface ozone increases resulting from land-use change on Borneo, excluding the impact of future changes in emissions elsewhere. Although the largest changes in this scenario occurred directly over Borneo, the model also calculated notable regional changes of $\mathrm{O}_{3}, \mathrm{OH}$ and other species downwind of Borneo and in the free troposphere.

\section{Introduction}

Forests in Borneo, and more generally South East Asia, are currently undergoing very rapid rates of land-use change as a result of logging or replacement by tree crops (e.g. FAO, 2005; MPOA, 2008). One of the most widespread crop monocultures in this region is oil palm (Elaeis guineensis), with Indonesia and Malaysia containing $60 \%$ of the global oil palm plantation area. Demand for palm oil has soared in recent years for use in cooking, domestic products and biofuels, driving a large expansion in plantation area. For example, $13 \%$ of land in Malaysia is now covered by oil palm, 
compared with $1 \%$ less than $40 \mathrm{yr}$ ago (Thoenes, 2007; Hewitt et al., 2010). In Kalimantan (Indonesian Borneo), oil palm coverage has increased from $<0.2 \%$ of total land area in 1990, to $6 \%$ in 2010 (Carlson et al., 2012). However, only a fraction of awarded leases have so far been converted to oil palm: if all current awarded leases were converted, plantations would cover $23 \%$ of Kalimantan $\left(125484 \mathrm{~km}^{2}\right)$.

This rapid change in land use could influence both atmospheric composition and climate in several key ways. Along with many types of vegetation, both rainforest and oil palm emit biogenic volatile organic compounds (BVOCs) to the atmosphere (Hewitt et al., 2009; Langford et al., 2010; Misztal et al., 2011). Isoprene is the dominant BVOC emitted, with an estimated global emission rate of $440-660 \mathrm{TgC}^{-1}$ (Guenther et al., 2006, 2012; Arneth et al., 2008), contributing an estimated $50 \%$ by mass to total BVOC emissions (Guenther et al., 2012). Different species of vegetation emit differing quantities of isoprene and other BVOCs (Guenther et al., 2006), therefore a switch from a rainforest to oil palm landscape will result in a change in isoprene emissions. The production of isoprene is also strongly temperature dependent and influenced by solar radiation, soil moisture and ambient $\mathrm{CO}_{2}$ levels (Guenther et al., 1995, 2012; Kesselmeier et al., 1999; Arneth et al., 2008). Changes in climate, as well as land use, will therefore influence emissions (Lathiére et al., 2006; Arneth et al., 2007; Ganzeveld et al., 2010). Isoprene is a major precursor to the formation of tropospheric ozone, an important atmospheric pollutant, and is highly reactive towards the hydroxyl radical $(\mathrm{OH})$, the troposphere's principal oxidant. Thus changes in isoprene emissions can alter the lifetime of greenhouse gases such as methane and hydrochlorofluorocarbons (e.g. Folberth et al., 2006).

A change in land use could also result in a change in surface fluxes of nitrogen oxides $\left(\mathrm{NO}_{\mathrm{x}}\right)$, through fertiliser application, industrial processing and transport. In the presence of $\mathrm{NO}_{\mathrm{x}}$ and sunlight, VOCs mediate the formation of ozone. The chemical processes controlling tropospheric ozone are complex, depending non-linearly on the relative local concentrations of $\mathrm{NO}_{\mathrm{x}}$ and VOCs (Liu et al., 1987; Sillman, 1995). In a low $\mathrm{NO}_{\mathrm{x}}$ or "clean" chemical regime, a decrease in $\mathrm{NO}_{\mathrm{x}}$ (or increase in VOC) might be expected to lead to a decrease in ozone. In contrast, in a high $\mathrm{NO}_{\mathrm{x}}$ or "polluted" chemical regime, a decrease in $\mathrm{NO}_{\mathrm{x}}$ (or an increase in VOC) might be expected to lead to an increase in ozone. At high concentrations ozone can be toxic to human health, forests and crops (Fowler, 2008). Therefore any changes to land use which alter isoprene and $\mathrm{NO}_{\mathrm{x}}$ emission rates could potentially have a significant influence on ozone and air quality (e.g. Hewitt et al., 2010; Ashworth et al., 2012).

There are, however, significant uncertainties concerning isoprene chemistry and the degree to which $\mathrm{OH}$ is consumed by the oxidation of isoprene, which could alter our understanding of the atmospheric impact of future changes in isoprene emissions. In particular, large discrepancies exist between measured and modelled $\mathrm{OH}$ concentrations in regions of high isoprene and low $\mathrm{NO}_{\mathrm{x}}$ emissions, suggesting the existence of an unknown chemical recycling mechanism for $\mathrm{OH}$ (Lelieveld et al., 2008; Hewitt et al., 2010; Whalley et al., 2011; Stone et al., 2011; Hofzumahaus et al., 2009). Several $\mathrm{HO}_{\mathrm{x}}\left(\mathrm{OH}\right.$ and $\left.\mathrm{HO}_{2}\right)$ regeneration mechanisms have been proposed to resolve these differences (e.g. Lelieveld et al., 2008; Peeters et al., 2009; Da Silva et al., 2010; Paulot et al., 2009). Inclusion of these mechanisms in model chemistry schemes has the potential to influence our understanding of the extent to which changes in isoprene emissions could affect oxidising capacity (Archibald et al., 2010b).

As part of the NERC OP3 project, a comprehensive set of biosphere-to-atmosphere flux and atmospheric composition measurements were made at both a natural rainforest and oil palm plantation site in the Malaysian state of Sabah, on the island of Borneo in 2008 (Langford et al., 2010; Misztal et al., 2010, 2011). Observations indicated increased fluxes of both isoprene and $\mathrm{NO}_{\mathrm{x}}$ over oil palm plantations relative to rainforest (Hewitt et al., 2009). Box model calculations by Hewitt et al. (2009) based on this oil palm isoprene flux data predicted that if levels of $\mathrm{NO}_{\mathrm{x}}$ in Borneo were allowed to reach those currently seen over rural North America and Europe, ground-level ozone mixing ratios would reach $\sim 100 \mathrm{ppb}$, far exceeding levels harmful to human health. However, potential changes in $\mathrm{NO}_{\mathrm{x}}$ emissions associated with a developing oil palm industry on Borneo were not fully quantified in this study.

Here, we use the global Cambridge p-TOMCAT chemical transport model, together with flux and atmospheric composition data collected during OP3, to investigate the atmospheric impacts of changes in isoprene and $\mathrm{NO}_{\mathrm{x}}$ emissions brought about through land-use change on Borneo. By using a global model, we are able to assess potential regional and global influences as well as changes in surface atmospheric composition that would directly affect air quality on Borneo. We focus on Borneo as this is a region that is currently experiencing rapid land-use change, and for which there is detailed measurement data available. Both a conventional isoprene oxidation scheme and a chemical mechanism including a representation of $\mathrm{OH}$ recycling are tested to explore the sensitivity of our results to uncertainties in chemistry. In Sect. 2, we describe OP3 measurements which form the basis of our model simulations. Section 3 contains a description of the model set-up and land-use change emission scenarios. Results from the model simulations are presented in Sect. 4 and are summarised in Sect. 5.

\section{Measurements}

In 2008, intensive measurements of atmospheric composition and chemistry were made during the OP3 field campaign in the Malaysian state of Sabah on the island of Borneo (Hewitt et al., 2010). The measurements used in this study are from the first two field deployments of this campaign: OP3-I 
from 8 April to 3 May, and OP3-II from 11 May to 20 June. OP3-I consisted of a set of extensive composition and flux measurements from within and above the rainforest canopy at the Bukit Atur Global Atmosphere Watch (GAW) station $\left(4^{\circ} 58^{\prime} \mathrm{N}, 117^{\circ} 50^{\prime} \mathrm{E}\right.$, elevation $\left.426 \mathrm{~m}\right)$ in Danum Valley. During OP3-II, a more limited set of measurements were made at the nearby Sabahmas oil palm plantation owned by Wilmar International Ltd. $\left(5^{\circ} 14^{\prime} \mathrm{N}, 118^{\circ} 27^{\prime} \mathrm{E}\right)$.

Marked differences in both isoprene and $\mathrm{NO}_{\mathrm{x}}$ concentrations were observed between the rainforest and oil palm plantation sites (Fowler et al., 2011; MacKenzie et al., 2011). Isoprene fluxes, measured using the virtual disjunct eddy covariance technique, were approximately five times larger at the oil palm site compared to the rainforest site (comparing peak daily fluxes) (Hewitt et al., 2009; Langford et al., 2010; Misztal et al., 2011). An increase in $\mathrm{NO}_{\mathrm{x}}$ emissions at oil palm plantations relative to rainforest was not measured directly, but was confirmed indirectly during overflights of both canopy types (Hewitt et al., 2009). Despite the larger isoprene and $\mathrm{NO}_{\mathrm{x}}$ fluxes at the oil palm plantation relative to the rainforest location, ozone mixing ratios over the two landscapes were similar, with values around $10 \mathrm{ppb}$. However, plumes of higher ozone were observed in air influenced by emissions from oil palm processing plants (Hewitt et al., 2010). Over the rainforest, $\mathrm{OH}$ concentrations were found to be an order of magnitude greater than daytime maximum $\mathrm{OH}$ concentrations predicted by measurements of the $\mathrm{OH}$ reactivity and estimates of the $\mathrm{OH}$ production rate based on all known OH sources (Whalley et al., 2011), supporting the existence of an unexplained $\mathrm{OH}$ source above tropical rainforests.

\section{Model set-up}

\subsection{Model description}

The model used for the simulations is the Cambridge pTOMCAT chemical transport model. It has been used extensively for tropospheric studies and is described in more detail in Cook et al. (2007) and Hamilton et al. (2008). For this study, the model was run at a relatively high horizontal resolution $\left(1^{\circ} \times 1^{\circ}\right.$, approximately $120 \mathrm{~km}$ in the tropics), with 31 vertical levels extending from the surface to $10 \mathrm{hPa}$. The horizontal and vertical transport of tracers was based on 6-hourly meteorological fields, including winds and temperatures, derived from the European Centre for Medium-Range Forecasts' (ECMWF) operational analyses. Tracer advection was calculated with the second-order moments advection scheme of Prather (1986), and convective transport was based on the mass flux scheme of Tiedkte (1989). The boundary layer height was diagnosed from input ECMWF operational analyses using the non-local vertical diffusion scheme of Holtslag and Boville (1993), as implemented in Wang et al. (1999).
The standard emission set-up for model simulations in this study includes $\mathrm{CO}, \mathrm{NO}_{\mathrm{x}}$ and non-methane hydrocarbon (NMHCs) emissions taken from ACCENT/IPCC AR4 (Stevenson et al., 2006). For methane, a fixed global annual 3-D mixing ratio field based on present-day values was used. Global isoprene emissions for the BASE scenario were taken from an integration of the MEGANv2.04 model using present-day input datasets of vegetation and climate (Ashworth et al., 2010; Guenther et al., 2006). In a selection of alternative scenarios (described in more detail in Sect. 3.3), emissions of isoprene and $\mathrm{NO}_{\mathrm{x}}$ over Borneo were replaced by emissions based on flux measurements taken during the OP3-I and OP3-II campaigns, emission factors and palm oil yields.

\subsection{Chemistry schemes}

Two different chemistry scenarios were included in the model integrations: one with, and one without a representation of $\mathrm{OH}$ recycling. The standard model mechanism (without $\mathrm{OH}$ recycling) is the same as described in Arnold et al. (2005), with the addition of the Mainz Isoprene Mechanism (Pöschl et al., 2000) implemented as described by Young et al. (2009). The model chemistry includes 63 chemical species and 177 reactions, simulating the oxidation of methane, ethane, propane and isoprene using the ASAD chemistry package (Carver et al., 1997). Photolysis rates for 37 species were determined using offline look-up tables generated by the Cambridge 2-D model (Law and Pyle, 1993) using the multiple scattering scheme of Hough (1988). These offline rates were based on climatological cloud cover and a fixed aerosol profile. The chemistry scheme is of medium complexity, comparable with the schemes employed in other tropospheric chemistry transport models, and has been used in the UM_CAM global model as well as the UKCA model (Zeng et al., 2010; Young et al., 2009; Morgenstern et al., 2008).

In a number of experiments, an additional $\mathrm{HO}_{\mathrm{x}}$ regeneration mechanism was included, based on the work of Peeters et al. (2009). Here, two additional reactions (R1 and R2; MACR = lumped C4 carbonyl, MGLY = methyl glyoxal and HACET $=$ hydroxylacetone) were implemented, following the method of Archibald et al. (2010b, 2011). Including the unimolecular reactions of the isoprene hydroxy peroxy radical $\left(\mathrm{ISOPOHO}_{2}\right)$ has been shown to improve the representation of low- $\mathrm{NO}_{\mathrm{x}}$ isoprene chemistry in both box model and global model studies (Archibald et al., 2010a, b).

$\mathrm{ISOPOHO}_{2} \rightarrow \mathrm{OH}+\mathrm{MACR}+\mathrm{HCHO}$

$\mathrm{ISOPOHO}_{2} \rightarrow 1.0 \mathrm{HO}_{2}+1.0 \times \mathrm{MGLY}+0.65 \times$ HACET $+0.6 \times \mathrm{OH}$

Several schemes have been proposed to regenerate $\mathrm{HO}_{\mathrm{x}}$ during isoprene oxidation. The simplest schemes postulated at 
Table 1. A description of the emission scenarios used in the p-TOMCAT simulations.

\begin{tabular}{llll}
\hline Scenario & \multicolumn{2}{c}{ Emissions in Borneo } & Chemical mechanism \\
& Isoprene & $\mathrm{NO}_{\mathrm{x}}$ & \\
\hline BASE & MEGAN & IPCC AR4 & Standard \\
FOREST & OP3 rainforest & IPCC AR4 & Standard \\
FOREST_OH & OP3 rainforest & IPCC AR4 & OH recycling \\
FIX & Prescribed surface mixing ratios & IPCC AR4 & Standard \\
FIX_OH & Prescribed surface mixing ratios & IPCC AR4 & OH recycling \\
PALM & OP3 oil palm & IPCC AR4 & Standard \\
PALMX & OP3 oil palm & Oil palm industry & Standard \\
PALMX_OH & OP3 oil palm & Oil palm industry & OH recycling \\
\hline
\end{tabular}

the time unknown mechanisms, which allowed $\mathrm{HO}_{2}$ to convert back to $\mathrm{OH}$ through reactions with organic peroxy radicals (Lelieveld et al., 2008). These schemes have since been shown, through a series of laboratory studies, to be only effective for a small subset of organic peroxy radicals and hence their suitability for incorporation into global model studies has been questioned (Archibald et al., 2010b). Here we have implemented a scheme based around the pioneering theoretical work of Peeters et al. (2009). The aim of including this scheme is to test the model's sensitivity to including $\mathrm{HO}_{\mathrm{x}}$ regeneration. We do note, however, that recent experimental evidence (Crounse et al., 2011) suggests that the formation of hydroperoxyaldehydes (crucial intermediates predicted by the Peeters mechanism) are very significantly slower than suggested by Peeters et al. (2009), so significant uncertainties remain in understanding $\mathrm{HO}_{\mathrm{x}}$ chemistry.

\subsection{Model scenarios}

The eight different model scenarios considered include five "present-day" and three "land-use change" scenarios and are summarised in Table 1. The first present-day scenario, BASE, includes the standard emissions and the chemical mechanism without $\mathrm{OH}$ recycling, as described in Sects. 3.1 and 3.2, respectively. The second present-day scenario, FOREST, replaces the MEGAN isoprene emissions over Borneo with a sine curve fit to observed diurnally varying forest isoprene fluxes from the OP3 campaign, shown in Fig. 1 (described in more detail in Langford et al., 2010). Although there are already extensive oil palm plantations on Borneo, we have classified this scenario as "present day" as the fraction of land covered by oil palm remains relatively small at $\sim 7 \%$, compared to the hypothetical complete oil palm coverage considered in our land-use change scenarios (MPOA, 2008; Carlson et al., 2012). As the temporal coverage of the measurements is too limited to provide information on the seasonality of emissions, the seasonality of the MEGAN isoprene fluxes was applied to the FOREST scenarios. The exact seasonal variation of the MEGAN emissions varies over Borneo; however, monthly emission rates are generally within $-20 \%$ and $+35 \%$ of the annual mean rate at each respec-

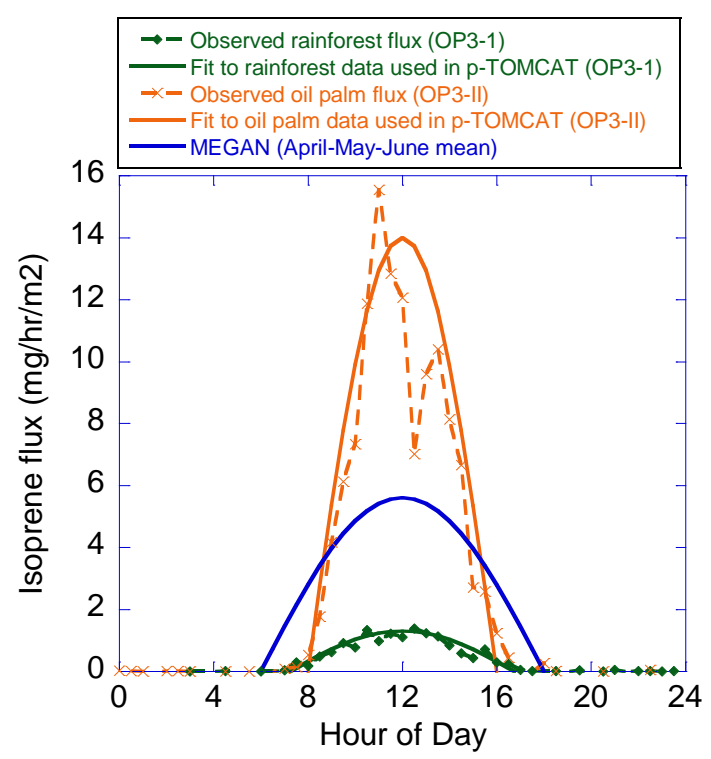

Fig. 1. MEGAN isoprene fluxes at Danum Valley compared to fluxes observed during OP3 at a rainforest and oil palm plantation site.

tive model grid point, with emissions peaking in March and August. The observed OP3 forest isoprene emissions are approximately four times lower than those calculated by the MEGAN model in the Danum Valley region and have a diurnal variation more tightly centred around midday (Fig. 1). In a final present-day scenario, FIX, the observed OP3 isoprene fluxes are replaced in the model by prescribed boundary layer isoprene mixing ratios, based on the average diurnal variation of observed mixing ratios recorded during OP3.

In a set of further scenarios, designed to assess the performance of the model and the potential impact of land-use change in Borneo on the atmosphere, the standard emissions of both isoprene and $\mathrm{NO}_{\mathrm{x}}$ over Borneo were replaced with fluxes based on observations made during the OP3 campaign. In the first of the land-use change scenarios, PALM, the entire island of Borneo was considered to be covered in oil palm. While this is clearly an extreme scenario, our aim was 

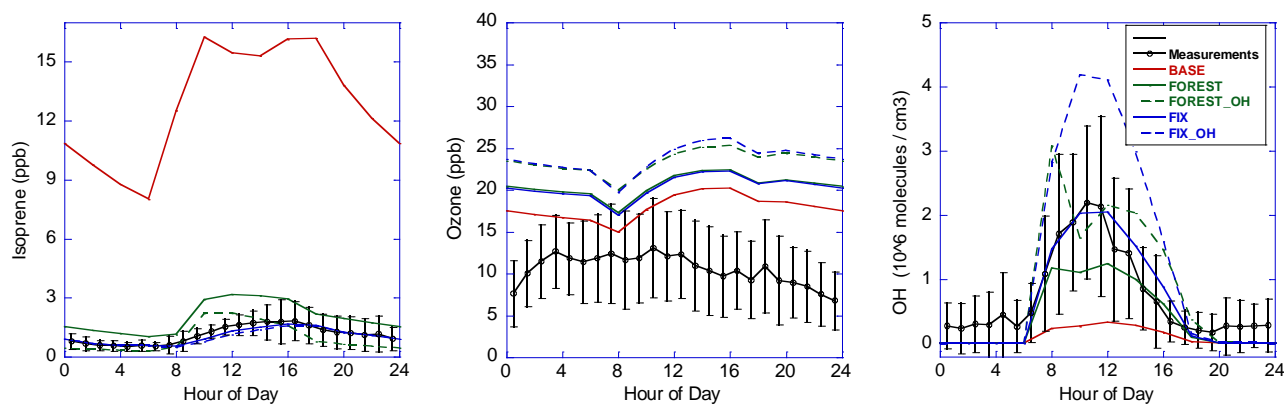

Fig. 2. A comparison of average diurnal cycles of isoprene, $\mathrm{OH}$ and ozone mixing ratios, measured at Bukit Atur, Danum Valley, during OP3I, to p-TOMCAT modelled mixing ratios from the five present-day emission/chemical mechanism scenarios. Error bars on the measurements show \pm 1 standard deviation.

to explore sensitivities rather than generate a "best guess", as there are significant uncertainties in projections of future oil palm extent. The NCAR vegetation distribution for 2001, based on ground-based observations and satellite retrievals, indicates that vegetation covering $90 \%$ of Borneo could potentially be converted to oil palm plantation (Guenther et al., 2006; NCAR, 2007). The REDD (Reducing Emissions from Deforestation and Forest Degradation) initiative indicates a much lower maximum potential oil palm coverage; however, many countries are currently growing oil palm in areas which REDD deems unsuitable (Stickler et al., 2007). Therefore, although a landscape exclusively devoted to oil palm is obviously an extreme situation, it is useful for exploring one possible future air quality trajectory. In this scenario, MEGAN isoprene emissions over Borneo were replaced by fluxes measured in a Borneo oil palm plantation during OP3 (Fig. 1). The OP3 oil palm isoprene fluxes were significantly larger than both the OP3 forest and the MEGAN fluxes, with peak daily fluxes exceeding the MEGAN values by a factor of $\sim 2.5$. All other emissions are unchanged from the BASE scenario.

The PALMX scenario includes $\mathrm{NO}_{\mathrm{x}}$ emissions from industrial processing and fertilisation of oil palm over Borneo, in addition to the larger oil palm isoprene emissions in PALM. $\mathrm{NO}_{\mathrm{x}}$ emissions from fertilised soils were based on OP3 observations of $\mathrm{N}_{2} \mathrm{O}$ and parameterisations of ratios of $\mathrm{NO}$ and $\mathrm{N}_{2} \mathrm{O}$ from croplands in SE Asia (Yan et al., 2003). They total $0.8 \mathrm{Mg}\left(\mathrm{NO}_{2}\right) \mathrm{km}^{-2} \mathrm{yr}^{-1}$ and were emitted as annual pulse emissions decaying linearly over a twomonth period following fertiliser application to a background flux of $0.05 \mathrm{~kg}\left(\mathrm{NO}_{2}\right) \mathrm{km}^{-2} \mathrm{yr}^{-1}$. The time of fertiliser application varied randomly with geographical location on Borneo, but remained the same for each model simulation. $\mathrm{NO}_{\mathrm{x}}$ emissions from industrial processing and transport were constant throughout the year and were calculated from estimates of the energy required to process oil palm and the type of fuel used. Following Reijnders and Huijbregts (2008), we assumed industrial processing energy requirements of $8 \mathrm{GJ} \mathrm{t}^{-1}$ (palm oil), and plantation cropping and local transport energy requirements of $3 \mathrm{GJ} \mathrm{t}^{-1}$ (palm oil), and that $100 \%$ of the energy required for transport and $75 \%$ of the energy required for processing was supplied by fossil fuel, with the remainder supplied by the burning of waste products, e.g. fibre and shells. Assuming a yield of $4 \mathrm{t}^{-1}$ (palm oil) $\mathrm{h}^{-1} \mathrm{yr}^{-1}$ (MPOA, 2008; Reijnders and Huijbregts, 2008), we estimated industrial $\mathrm{NO}_{\mathrm{x}}$ emissions of $1.24 \mathrm{Mg}\left(\mathrm{NO}_{2}\right) \mathrm{km}^{-2} \mathrm{yr}^{-1}$. Including both oil palm industrial and fertilisation sources, $\mathrm{NO}_{\mathrm{x}}$ emissions total $0.07 \mathrm{mg}(\mathrm{N}) \mathrm{m}^{-2} \mathrm{~h}^{-1}$, which is greater than, but the same order of magnitude, as oil palm $\mathrm{NO}_{\mathrm{x}}$ fluxes of $0.019 \mathrm{mg}(\mathrm{N}) \mathrm{m}^{-2} \mathrm{~h}^{-1}$ at the landscape scale inferred by Hewitt et al. (2009). For comparison, baseline $\mathrm{NO}_{\mathrm{x}}$ emissions over Borneo in the present-day scenario are 0.006 to $0.010 \mathrm{mg}(\mathrm{N}) \mathrm{m}^{-2} \mathrm{~h}^{-1}$ (compared to 0.009 in Hewitt et al., 2009).

All emission scenarios were run with the standard model chemistry without $\mathrm{OH}$ recycling. In addition, the FOREST, FIX and PALMX scenarios were also simulated using the $\mathrm{OH}$ recycling chemistry described in Sect. 3.2 (see Table 1). Further to the eight model scenarios outlined in Table 1, we performed two additional variant simulations of FOREST and PALMX, assessing the sensitivity of the model to variations in ozone deposition velocities over Borneo. Each model scenario was run for one year using 2008 meteorological fields, following a six month model spin-up period. Six months was found to be sufficient for the model to adjust to changes in emissions of isoprene and $\mathrm{NO}_{\mathrm{x}}$, both short-lived species, over a limited geographical area.

\section{Results}

\subsection{Model analysis}

Before performing the land-use change model simulations, we first assessed the model simulations against present-day atmospheric data from the OP3 campaign and tested the sensitivity of the model to uncertainties in chemical and physical terms of the ozone budget. Figure 2 shows comparisons of isoprene, $\mathrm{OH}$ and ozone mixing ratios from the five 
present-day model scenarios described in Table 1 with observations made during OP3 in Danum Valley. As Danum Valley is only $50 \mathrm{~km}$ from the coast, the corresponding grid point in the $\sim 1^{\circ} \times 1^{\circ}(\sim 120 \times 120 \mathrm{~km})$ simulations is heavily influenced by ocean processes. Therefore, we compare the observations with model data from an adjacent inland grid box to the west of Danum Valley.

The BASE scenario, which uses the MEGAN isoprene emissions and standard chemical mechanism without any $\mathrm{OH}$ recycling, results in isoprene mixing ratios much larger than observations (by approximately a factor of 8) and modelled $\mathrm{OH}$ concentrations that are significantly less than observations (by approximately a factor of 5). Using the lower, observed isoprene fluxes in the FOREST scenario (see Fig. 1) improves the comparison of both isoprene and $\mathrm{OH}$ modelled concentrations with observations, although peak isoprene remains too high (by $\sim 70 \%$ ) and $\mathrm{OH}$ too low (by $\sim 45 \%$ ) in the model (Fig. 2). If $\mathrm{OH}$ recycling chemistry is included in the FOREST scenario, modelled $\mathrm{OH}$ concentrations increase in line with observations and the agreement between modelled and observed isoprene improves. However, the model produces a morning peak in $\mathrm{OH}$ concentration that is not seen in the measurement data. This peak in $\mathrm{OH}$ may arise as the diurnal variation of the FOREST isoprene fluxes emits isoprene over a shorter section of the day than MEGAN, resulting in a period during the morning where sunlight is generating $\mathrm{OH}$, but isoprene is not yet being emitted, thus there is a reduced sink for $\mathrm{OH}$.

The best fit to the $\mathrm{OH}$ observations is provided by the FIX scenario without $\mathrm{OH}$ recycling chemistry, where isoprene mixing ratios in the boundary layer over Borneo are fixed according to the atmospheric observations (rather than using the flux measurements) at Danum Valley. When the isoprene mixing ratios (rather than the isoprene fluxes) are prescribed to follow the observations, the model is able to reproduce observations of $\mathrm{OH}$ without requiring any $\mathrm{HO}_{\mathrm{x}}$ recycling. However, our model-calculated $\mathrm{OH}$ reactivities are significantly less than suggested by measurements (a peak daily maximum of $\sim 7 \mathrm{~s}^{-1}$ compared to $\sim 24 \mathrm{~s}^{-1}$ ) (Whalley et al., 2011), indicating we may be underestimating $\mathrm{OH}$ reactivities. Edwards et al. (2013) have shown that the emission of isoprene constitutes a significantly larger emission of reactivity than is offered by the primary reaction of isoprene alone, suggesting a large contribution from secondary oxidation products of isoprene. In this case, the development of measurement techniques for secondary multifunctional carbon compounds would be required to close the $\mathrm{OH}$ reactivity budget. Differences in simulated $\mathrm{OH}$ between the five present-day scenarios demonstrate that modelled $\mathrm{OH}$ concentrations are at least as sensitive to uncertainties in isoprene emissions as uncertainties in $\mathrm{HO}_{\mathrm{x}}$ regeneration chemical mechanisms.

In the BASE, FOREST and FIX simulations, model surface grid points (land and ocean) surrounding Danum Valley encompass the $\mathrm{OP} 3 \mathrm{NO}_{\mathrm{x}}$ observations, capturing the phase of the diurnal cycle, but with values both significantly higher, and lower, than observed locally. For example, modelled April surface monthly mean $\mathrm{NO}_{2}$ mixing ratios vary from $\sim 200 \mathrm{ppt}$ in coastal areas to $600 \mathrm{ppt}$ in inland hotspots. In comparison, the median $\mathrm{NO}_{2}$ diurnal profile at Danum Valley for the entire April measurement period ranges from $80 \mathrm{ppt}$ in the mid-afternoon to just below 300 ppt just after midnight (Hewitt et al., 2010; Pike et al., 2010).

Ozone in all the model scenarios is higher than the observations, which may lead to an overestimate in $\mathrm{OH}$ production through $\mathrm{O}\left({ }^{1} \mathrm{D}\right)+\mathrm{H}_{2} \mathrm{O} \rightarrow 2 \mathrm{OH}$. In the FIX scenario, which performs best for capturing $\mathrm{OH}$ observations, modelled ozone mixing ratios are approximately double those observed. These local differences may arise partly as a result of model resolution. Using a similar set-up of p-TOMCAT, but with different emission scenarios, Pike et al. (2010) found that increasing the model resolution improved the comparison between modelled and observed ozone at Danum Valley. Improving the resolution resulted in a more realistic representation of deposition, an important loss process for ozone, due to a higher resolution land-sea mask and improved representation of the land surface type. Although the model simulations presented here are performed at a high resolution of $\sim 1^{\circ} \times 1^{\circ}$ to minimise these impacts, resolution may still play a role. In addition, part of the difference between modelled and observed ozone may also arise as a result of the complex topography and boundary layer dynamics around Danum Valley, which will introduce difficulties when comparing global model data to measurements at this site. Pike et al. (2010) could not model the observed diurnal variation of ozone and $\mathrm{NO}_{\mathrm{x}}$ at Danum Valley without introducing an idealised treatment of the boundary layer. In order to test whether calculated regional perturbations in ozone are robust to model uncertainties within the present-day ozone budget, we perform two additional sensitivity simulations (not shown in Table 1), which are described in Sect. 4.2.

\subsection{Land-use change impacts}

Figures 3 and 4 show the monthly mean percentage change in surface $\mathrm{O}_{3}$ and $\mathrm{OH}$ between the FOREST and PALM, and FOREST and PALMX emission scenarios for June and December. We have chosen to use FOREST as our base presentday scenario, so all scenarios consistently use isoprene fluxes observed during OP3 either from the rainforest or oil palm plantation locations.

The increase in isoprene emissions between the FOREST and PALM scenarios results in decreases in $\mathrm{O}_{3}$ over Borneo of up to $20 \%$ (or $\sim 5 \mathrm{ppb}$, see Fig. $3 \mathrm{a}$ and c). Decreases in ozone arise as in the unpolluted, low $\mathrm{NO}_{\mathrm{x}}$ environment of the rainforest, an increase in VOC concentration results in an increased net chemical sink for ozone. However, when increases in $\mathrm{NO}_{\mathrm{x}}$ emissions are also considered in addition to the isoprene increases (PALMX), the combined increases in $\mathrm{NO}_{\mathrm{x}}$ and $\mathrm{VOC}$ concentrations lead to an increase in the chemical production of ozone. Monthly mean surface $\mathrm{NO}_{2}$ 

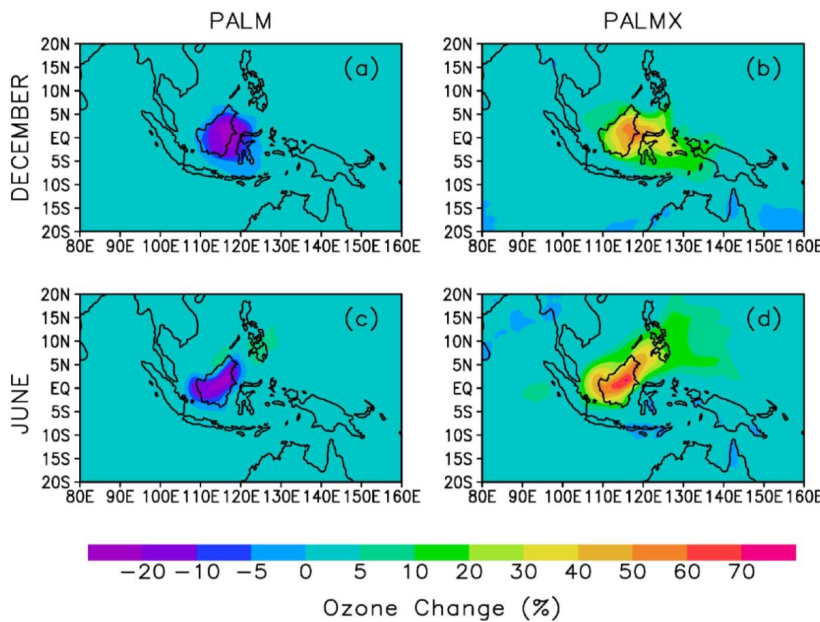

Fig. 3. Percentage difference in June and December surface mean ozone mixing ratios between the FOREST and PALM, and FOREST and PALMX scenarios: (a) December (PALM-FOREST)/FOREST, (b) December (PALMX-FOREST)/FOREST, (c) June (PALM-FOREST)/FOREST) and (d) June (PALMX-FOREST)/FOREST.
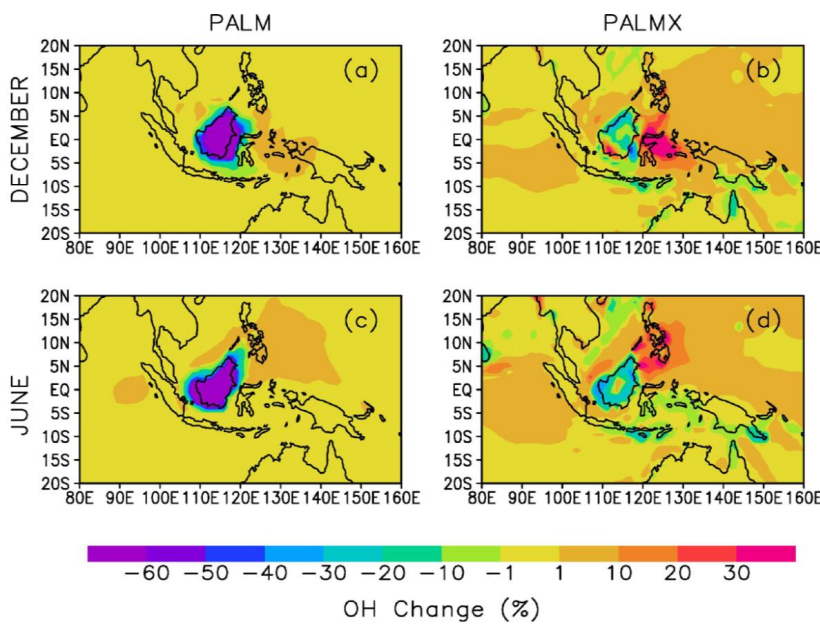

Fig. 4. Percentage difference in June and December surface mean $\mathrm{OH}$ concentrations between the FOREST and PALM, and FOREST and PALMX scenarios: (a) December (PALM-FOREST)/FOREST, (b) December (PALMX-FOREST)/FOREST, (c) June (PALM-FOREST)/FOREST) and (d) June (PALMX-FOREST)/FOREST.

increases by a factor of between 2 and 4 (corresponding to an increase of up to $1 \mathrm{ppb}$ ), and surface $\mathrm{O}_{3}$ increases by up to $70 \%$ (see Fig. $3 b$ and d) relative to the FOREST scenario. However, due to the statistical nature of the $\mathrm{NO}_{\mathrm{x}}$ emissions, exact ozone budget statistics for this scenario vary substantially in time and space. Present-day ozone mixing ratios are low in this region and a $70 \%$ increase in surface ozone as shown in Fig. $3 \mathrm{~b}$ raises monthly mean modelled surface ozone mixing ratios to $\sim 30-45 \mathrm{ppb}$ over Borneo, with the highest values (up to $55 \mathrm{ppb}$ ) occurring during the northern hemispheric summer. Epidemiological studies suggest adverse health impacts are detectable above $35 \mathrm{ppb}$ (see, e.g. Pattenden et al., 2010). As well as impacting human health, ozone has also been shown to have a strong effect on photosynthesis and crop production, with damage to plants and yield reductions occurring at mixing ratios as low as $20 \mathrm{ppb}$ (Long et al., 2005). In the PALMX scenario, monthly mean ozone mixing ratios exceed $20 \mathrm{ppb}$ everywhere over Borneo year-round. However, monthly mean $\mathrm{O}_{3}$ mixing ratios of 30$45 \mathrm{ppb}$ remain less than surface ozone mixing ratios currently observed in polluted regions of the Northern Hemisphere. If the calculated maximum increase of $70 \%$ is applied to observed ozone mixing ratios, which are lower than the model calculated ozone levels, the ozone increase would result in monthly mean mixing ratios of only $\sim 20 \mathrm{ppb}$.

These results demonstrate the importance of understanding $\mathrm{NO}_{\mathrm{x}}$ emissions when predicting the impact of oil palm expansion on air quality. Hewitt et al. (2009) used box model simulations, combined with the same OP3 isoprene flux measurements as this study, to show that surface ozone over oil palm plantations could reach $100 \mathrm{ppb}$ if $\mathrm{NO}_{\mathrm{x}}$ concentrations were allowed to reach levels currently seen over rural North America and Europe. In our PALMX simulation, where all the land area in Borneo is converted to oil palm, $\mathrm{NO}_{\mathrm{x}}$ emissions from fertilisation and the oil palm industry are not large enough to increase $\mathrm{NO}_{\mathrm{x}}$ mixing ratios to these levels. Daytime mean $\mathrm{NO}_{2}$ in PALMX (as defined in Hewitt et al., 2009) remains below $\sim 0.6 \mathrm{ppb}$ over much of Borneo, only exceeding this value (but remaining $<1 \mathrm{ppb}$ ) at model grid points where the statistical $\mathrm{NO}_{2}$ emissions from fertilisation are turned on. In the Hewitt et al. (2009) study, daytime mean $\mathrm{NO}_{2}$ mixing ratios of $>1 \mathrm{ppb}$ are required to increase daytime mean ozone mixing ratios above the World Health Organization $8 \mathrm{~h}$ mean air quality threshold of $50 \mathrm{ppb}$.

Although the largest changes in $\mathrm{O}_{3}$ in PALMX are seen directly over Borneo, notable ozone increases are also calculated downwind and above in the free troposphere. The exact location of the downwind $\mathrm{O}_{3}$ changes varies with seasonal changes in meteorology (for example, compare Fig. $3 \mathrm{~b}$ and $\mathrm{d}$ for June and December). At an altitude of $500 \mathrm{hPa}$, increases in $\mathrm{O}_{3}$ over Borneo remain as high as $20 \%$.

The increase in isoprene emissions between the FOREST and PALM scenarios results in large surface decreases in $\mathrm{OH}$ over Borneo of up to $70 \%$ (see Fig. $4 \mathrm{a}$ and c). As $\mathrm{OH}$ is the primary oxidant in the atmosphere, this change will influence the mixing ratios of other species; for example, the model calculates increases in surface monthly mean $\mathrm{CO}$ of up to $25 \%$ over Borneo. Including the increased $\mathrm{NO}_{\mathrm{x}}$ emissions as well as the isoprene increases (PALMX) reduces the extent of the $\mathrm{OH}$ reduction over Borneo, with maximum $\mathrm{OH}$ decreases of $\sim 40 \%$ (Fig. $4 \mathrm{~b}$ and d). Downwind, where the short-lived isoprene has been removed, but longer-lived 


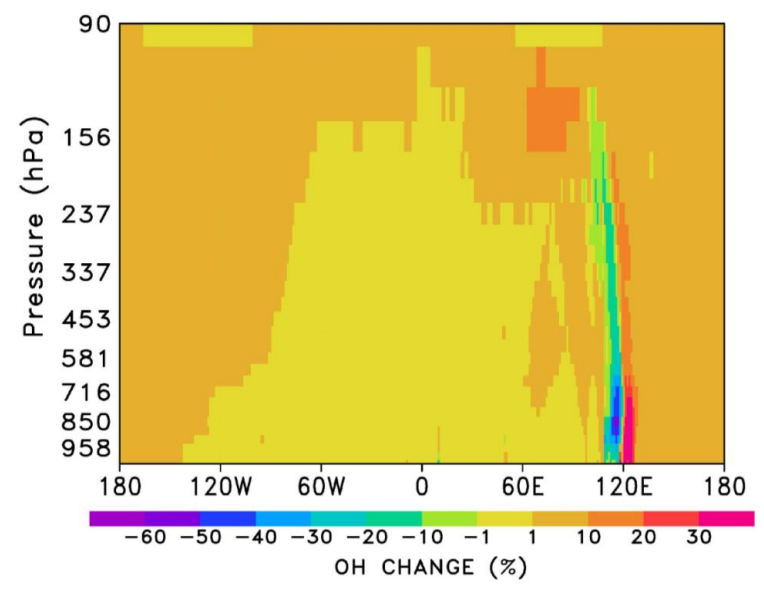

Fig. 5. Percentage difference in the December monthly mean distribution of $\mathrm{OH}$ concentrations between the FOREST and PALMX scenario ((PALMX-FOREST)/FOREST) for a vertical cross section along the Equator.

$\mathrm{O}_{3}$ remains high, the PALMX scenario also produces increases in surface $\mathrm{OH}$ of $>30 \%$. As for $\mathrm{O}_{3}$, large changes in $\mathrm{OH}$ are also calculated above in the free troposphere (see Fig. 5). At $500 \mathrm{hPa}$, the dipole structure of the $\mathrm{OH}$ changes is still present, with differences in concentrations ranging from $-20 \%$ to $+20 \%$. The model also calculates large changes in PAN between the FOREST and PALMX scenarios above Borneo and downwind in the free troposphere (Figs. 6 and 7). At $500 \mathrm{hPa}$, PAN increases of over $20 \%$ are seen downwind over the Pacific Ocean.

Figures 8 and 9 show percentage monthly mean changes in surface $\mathrm{O}_{3}$ and $\mathrm{OH}$ resulting from switching from the FOREST_OH to the PALMX_OH model scenarios, demonstrating the impact of including $\mathrm{OH}$ recycling. The pattern and magnitude of the changes in both species are very similar to the standard chemistry scenarios where $\mathrm{OH}$ recycling is not considered, showing that although $\mathrm{OH}$ recycling may be important for understanding absolute concentrations of these species, including it in the model does not significantly alter the magnitude of calculated changes in $\mathrm{O}_{3}$ occurring as a result of land-use change.

In order to test whether calculated perturbations in ozone are robust to model uncertainties within the present-day ozone budget, we perform two additional sensitivity simulations (not shown in Table 1), equivalent to FOREST and PALMX, except the ozone deposition velocities over Borneo are doubled. In both the FOREST and PALMX cases, doubling the ozone deposition velocities reduces surface ozone at Danum Valley by $\sim 25 \%$. The average percentage increase in ozone, moving from the FOREST to PALMX scenario, remains approximately the same $(\sim 66 \%$ in the model grid box chosen to represent Danum Valley) for the standard and doubled deposition velocity simulations (not shown). In addition, the percentage change in ozone between FOREST and

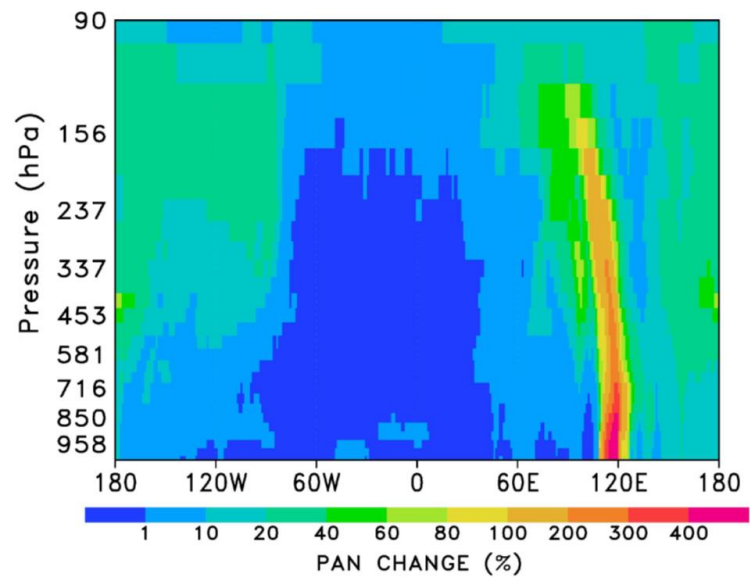

Fig. 6. Percentage difference in the December monthly mean distribution of PAN mixing ratios between the FOREST and PALMX scenario ((PALMX-FOREST)/FOREST) for a vertical cross section along the Equator.

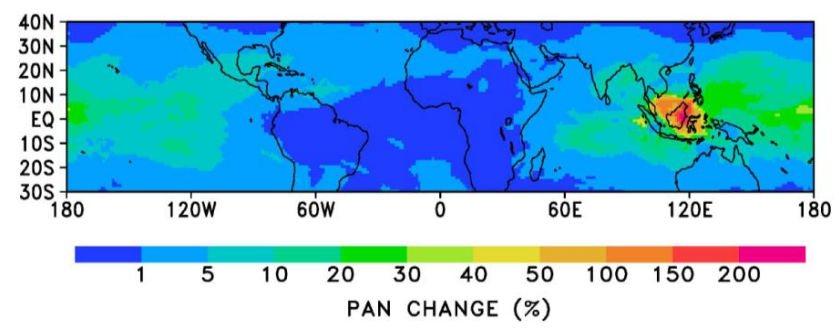

Fig. 7. Percentage difference in December monthly mean PAN mixing ratios between the FOREST and PALMX scenario ((PALMX-FOREST)/FOREST) at $500 \mathrm{hPa}$.

PALMX using the standard chemical mechanism, and FOREST_OH and PALMX_OH including $\mathrm{OH}$ recycling, remains approximately the same (54\% in the model grid box chosen to represent Danum Valley). This indicates that the modelcalculated perturbations in ozone are robust to uncertainties in both chemical and physical mechanisms within the model.

\section{Conclusions}

Before performing the land-use change simulations, the model was first assessed against present-day atmospheric data from the OP3. The BASE scenario, using the MEGAN isoprene emissions and standard chemical mechanism without any $\mathrm{OH}$ recycling, overestimated isoprene and underestimated $\mathrm{OH}$ concentrations relative to observations. Using the lower, observed isoprene fluxes and $\mathrm{OH}$ recycling chemistry substantially improved the comparison of both isoprene and $\mathrm{OH}$ modelled concentrations with observations. We found that for the model scenarios developed in this study, modelled $\mathrm{OH}$ concentrations were at least as sensitive to uncertainties in isoprene emissions as those in $\mathrm{HO}_{\mathrm{x}}$ regeneration 


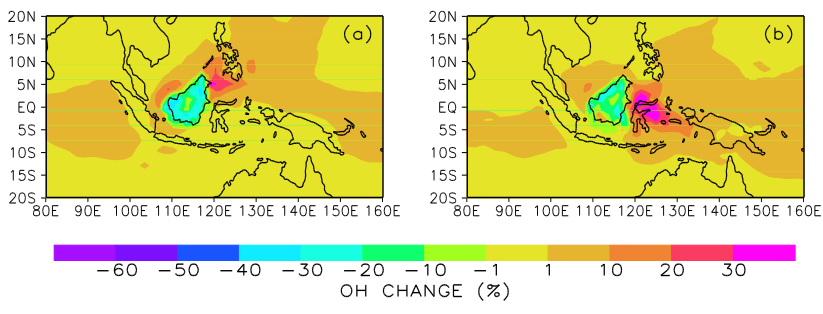

Fig. 8. As Fig. $4 b$ and $d$, but using $\mathrm{OH}$ recycling chemistry. This figure shows the percentage difference in $\mathrm{OH}$ between the PALMX_OH and FOREST_OH scenarios ((PALMX_OH-FOREST_OH)/FOREST_OH) for (a) June and (b) December.

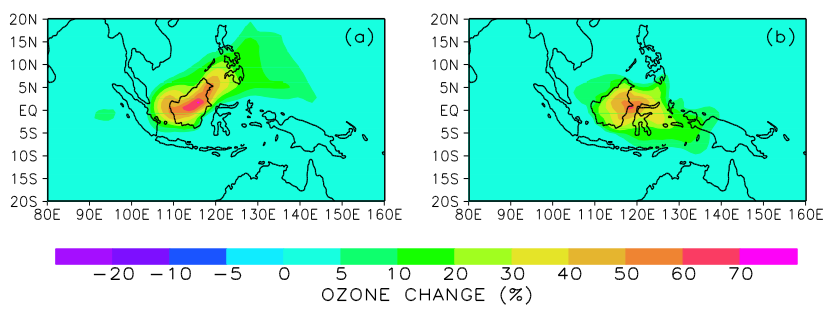

Fig. 9. As Fig. $3 b$ and $d$, but using $\mathrm{OH}$ recycling chemistry. This figure shows the percentage difference in $\mathrm{O}_{3}$ between the PALMX_OH and FOREST_OH scenarios ((PALMX_OH-FOREST_OH)/FOREST_OH) for (a) June and (b) December.

chemical mechanisms. However, significant uncertainties remain in understanding $\mathrm{HO}_{\mathrm{x}}$ chemistry. Stone et al. (2011) implemented a variety of mechanistic changes to a box model based on MCM chemistry, and found that none of the mechanistic suggestions available could reconcile both simulated $\mathrm{OH}$ and $\mathrm{HO}_{2}$ with observations. Pugh et al. $(2010,2011)$ demonstrated that part of the discrepancy between observations and modelled $\mathrm{OH}$ could be explained by incomplete mixing of isoprene in the boundary layer leading to segregation between isoprene and $\mathrm{OH}$ mixing ratios, which could be captured in models by using a reduced effective rate constant for their reaction. However, the effective rate constant reduction for the reaction of isoprene with $\mathrm{OH}$ was calculated to be typically $<15 \%$, well below the $50 \%$ reduction that would be required by models to be able to reconcile their $\mathrm{OH}$ and isoprene concentrations with measurements.

Results from the changing land-use simulations demonstrate that oil palm expansion in Borneo has the potential to alter local air quality as well as regional atmospheric composition. Simulations where fluxes of isoprene only, and fluxes of isoprene and $\mathrm{NO}_{\mathrm{x}}$ are varied, show that the magnitude of $\mathrm{NO}_{\mathrm{x}}$ fluxes is critical for determining changes in ozone resulting from land-use change. Scenarios considering only increases in isoprene fluxes calculate large percentage decreases in both surface ozone and $\mathrm{OH}$ over Borneo of 20 and $70 \%$, respectively. If changes in $\mathrm{NO}_{\mathrm{x}}$ emissions are also considered (PALMX), concentrations of $\mathrm{OH}$ decrease above Borneo, but to a lesser extent than when $\mathrm{NO}_{\mathrm{x}}$ changes are not included. Monthly mean surface ozone increases by up to $70 \%$ to $\sim 30-45 \mathrm{ppb}$ over Borneo, with regional increases exceeding 10-20\% downwind and in the free troposphere. Monthly mean surface ozone levels of $\sim 30$ to $45 \mathrm{ppb}$ are above the minimum mixing ratio at which ozone is believed to cause adverse health impacts and crop damage, but remain below present-day reported levels of $\mathrm{NO}_{\mathrm{x}}$ in other polluted regions of the Northern Hemisphere. Of course, ozone mixing ratios calculated in PALMX exclude any increases in background ozone resulting from increases in remote pollution sources. If additional increases in $\mathrm{NO}_{\mathrm{x}}$ emissions from other developing industries on Borneo, or increases in the transport of $\mathrm{NO}_{\mathrm{x}}$ (via PAN) from SE Asia were to be included, larger ozone increases would be expected. Including $\mathrm{OH}$ recycling does not significantly alter the magnitude of calculated changes in $\mathrm{O}_{3}$ occurring as a result of land-use change.

Although the largest changes are found locally, results from these calculations suggest that the impact of land-use changes will not be confined to Borneo, but that notable changes will also occur throughout the free troposphere and downwind of Borneo. Only changes in emissions from Borneo have been considered in the scenarios presented here. If changes over the tropics as a whole (Africa, South America, etc.) had been included, a larger free tropospheric response would be expected. However, the location of land-use change is important and surface ozone could go up as well as down, depending on the extent of land-use change and background $\mathrm{NO}_{\mathrm{x}}$ levels. For example, Ashworth et al. (2012) found that some areas of the tropics experienced a reduction in ozone under land-use change as ozone destruction outweighed ozone formation, indicating that each region should be considered specifically.

Other feedbacks not considered in this study may also influence the impact of land-use change in this region on atmospheric composition. For example, Fowler et al. (2011) found that deposition velocities to the rainforest in Borneo were a factor of 2 larger than over oil palm, which could lead to further increases in ozone on top of those calculated in our PALMX scenario. In addition, the impact of deforestation on precipitation (Spracklen et al., 2012) and physiological and structural vegetation feedbacks in a changing climate (Betts et al., 1997) could also play a role.

Acknowledgements. KA acknowledges funding from a NERC studentship and the QUEST-QUAAC project (NE/C001621/1). This paper is Publication No. A/603 of the Royal Society South East Asia Rainforest Research Programme. The authors would like to thank DVMC and EPC for granting research permission.

Edited by: W. T. Sturges 


\section{References}

Archibald, A. T., Jenkin, M. E., and Shallcross, D. E.: An isoprene mechanism intercomparison, Atmos. Environ., 44, 5356-5364, doi:10.1016/j.atmosenv.2009.09.016, 2010a.

Archibald, A. T., Cooke, M. C., Utembe, S. R., Shallcross, D. E., Derwent, R. G., and Jenkin, M. E.: Impacts of mechanistic changes on $\mathrm{HO}_{\mathrm{x}}$ formation and recycling in the oxidation of isoprene, Atmos. Chem. Phys., 10, 8097-8118, doi:10.5194/acp-108097-2010, 2010b.

Archibald, A. T., Levine, J. G., Abraham, N. L., Cooke, M. C., Edwards, P. M., Heard, D. E., Jenkin, M. E., Karunaharan, A., Pike, R. C., Monks, P. S., Shallcross, D. E., Telford, P. J., Whalley, L. K., and Pyle, J. A.: Impacts of $\mathrm{HO}_{\mathrm{x}}$ regeneration and recycling in the oxidation of isoprene; Consequences for the composition of past, present and future atmospheres, Geophys. Res. Lett., 38, L05804, doi:10.1029/2010/GL046520, 2011.

Arneth A., Miller, P., Scholze, M., Hickler, T., Schurgers, G., Smith, B., and Prentice, I. C.: $\mathrm{CO}_{2}$ inhibition of terrestrial isoprene emissions: potential implication for atmospheric chemistry, Geophys. Res. Lett., 34, L18813, doi:10.1029/2007GL030615, 2007.

Arneth, A., Monson, R. K., Schurgers, G., Niinemets, U., and Palmer, P. I.: Why are estimates of global terrestrial isoprene emissions so similar (and why is this not so for monoterpenes)?, Atmos. Chem. Phys., 8, 4605-4620, doi:10.5194/acp-8-46052008, 2008.

Arnold, S. R., Chipperfield, M. P., and Blitz, M. A.: A threedimensional model study of the effect of new temperaturedependent quantum yields for acetone photolysis, J. Geophys. Res., 110, D22305, doi:10.1029/2005JD005998, 2005.

Ashworth, K., Hewitt, C. N., and Wild, O.: Sensitivity of isoprene emissions estimated using MEGAN to the time resolution of input climate data. Atmos. Chem. Phys., 10, 1193-1201, doi:10.5194/acp-10-1193-2010, 2010.

Ashworth, K., Folberth, G., Hewitt, C. N., and Wild, O.: Impacts of near-future cultivation of biofuel feedstocks on atmospheric composition and local air quality, Atmos. Chem. Phys., 12, 919939, doi:10.5194/acp-12-919-2012, 2012.

Betts, R. A., Cox, P. M., Lee, S. E., and Woodward, F. I.: Contrasting physiological and structural vegetation feedbacks in climate change simulations, Nature, 387, 796-799, 1997.

Carlson, K. M., Curran, L. M., Asner, G. P., McDonald Pittman, A., Trigg, S. N., and Adeney, J. M.: Carbon emissions from forest conversion by Kalimantan oil palm plantations, Nature Clim. Change, 3, 283-287, doi:10.1038/nclimate1702, 2012.

Carver G. D., Brown P. D., and Wild O.: The ASAD atmospheric chemistry integration package and chemical reaction database, Comp. Phys. Comm., 105, 197-215, 1997.

Crounse, J. D., Paulot, F., Kjaergaard, H. G., and Wennberg, P. O.: Peroxy radical isomerization in the oxidation of isoprene, Phys. Chem. Chem. Phys., 13, 13607-13613, 2011.

Cook, P. A., Savage N. H., Turquety S., Carver G. D., O'Connor F. M., Heckel A., Stewart D., Whalley L. K., Parker A. E., Schlager H., Singh H. B., Avery M. A., Sachse G. W., Brune W., Richter A., Burrows J. P., Purvis R., Lewis A. C., Reeves C. E., Monks P. S., Levine J. G., and Pyle J. A.: Forest fire plumes over the North Atlantic: p-TOMCAT model simulations with aircraft and satellite measurements from the ITOP/ICARTT campaign, J. Geophys. Res., 112, D10S43, doi:10.1029/2006JD007563, 2007. da Silva, G., Graham, C., and Wang, Z.-F., Unimolecular ?Hydroxyperoxy Radical Decomposition with $\mathrm{OH}$ Recycling in the Photochemical Oxidation of Isoprene, Environ. Sci. Technol., 44, 250-256, doi:10.1021/es900924d, 2010.

FAO, Global Forest Resources: Assessment 2005, Rome, ISBN-925-105481-9, 2006.

Folberth, G. A., Hauglustaine, D. A., Lathiere, J., and Brocheton, F.: Interactive chemistry in the Laboratoire de Meteorologie Dynamique general circulation model: model description and impact analysis of biogenic hydrocarbons on tropospheric chemistry, Atmos. Chem. Phys., 6, 2273-2319, doi:10.5194/acp-62273-2006, 2006.

Fowler, D.: Ground-level ozone in the 21st Century: future trends, impacts and policy implications, Royal Society, London, UK, 2008.

Fowler, D., Nemitz, E., Misztal, P., Di Marco, C., Skiba, U., Ryder, J., Helfter, C., Cape, J. N., Owen, S. M., Coyle, M., Phillips, G., Davison, B., Langford, B., MacKenzie, A. R., Muller, J., Siong, J., Pyle, J. A., and Hewitt, C. N.: Effects of land use on trace gas emissions and deposition in Borneo: comparing atmospheresurface exchange over oil palm plantations with a rainforest, Phil. Trans. R. Soc. B, 366, 3196-3209, doi:10.1098/rstb.2011.0055, 2011.

Ganzeveld, L., Bouwman, L., Stehfest, E., van Vuuren, D. P., Eickhout, B., and Lelieveld, J.: Impact of future land use and land cover changes on atmospheric chemistry-climate interactions. J. Geophys. Res., 115, D23301, doi:10.1029/2010JD014041, 2010.

Guenther, A., Hewitt C. N., Erickson D., Fall R., Geron C., Graedel T., Harley P., Klinger L., Lerdau M., McKay W. A., Pierce T., Scholes B., Steinbrecher R., Tallamraju R., Taylor J., and Zimmerman P.: A global model of natural volatile organic compound emissions, J. Geophys. Res., 100, 8873-8892, doi:10.1029/94JD02950, 1995.

Guenther, A., Karl, T., Harley, P., Wiedinmyer, C., Palmer, P. I., and Geron, C.: Estimates of global terrestrial isoprene emissions using MEGAN (Model of Emissions of Gases and Aerosols from Nature), Atmos. Chem. Phys., 6, 3181-3210, doi:10.5194/acp-63181-2006, 2006.

Guenther, A. B., Jiang, X., Heald, C. L., Sakulyanontvittaya, T., Duhl, T., Emmons, L. K., and Wang, X.: The Model of Emissions of Gases and Aerosols from Nature version 2.1 (MEGAN2.1): an extended and updated framework for modeling biogenic emissions, Geosci. Model Dev., 5, 1471-1492, doi:10.5194/gmd-51471-2012, 2012.

Hamilton, J. F., Allen, G., Watson, N. M., Lee, J. D., Saxton,, J. E., Lewis, A. C., Vaughan, G., Bower, K. N., Flynn, M. J., Crosier, J., Carver, G. D., Harris, N. R. P., Parker, R. J., Remedios, J. J., and Richards, N. A. D.: Observations of an atmospheric chemical equator and its implications for the tropical warm pool region, J. Geophys. Res., 113, D20313, doi:10.1029/2008JD009940, 2008.

Hewitt, C. N., MacKenzie, A. R., Di Carlo, P., Di Marco, C. F., Dorsey, J. R., Evans, M., Fowler, D., Gallagher, M. W., Hopkins, J. R., Jones, C. E., Langford, B., Lee, J. D., Lewis A. C., Lim, S. F., McQuaid, J., Misztal, P., Moller, S. J., Monks, P. S., Nemitz, E., Oram, D. E., Owen, S. M., Phillips, G. J., Pugh, T. A., M., Pyle, J. A., Reeves, C. E., Ryder, J., Siong, J., Skiba, U., and Stewart, D. J.: Nitrogen management is essential to prevent tropical oil palm plantations from causing ground-level ozone pollution, Proc. Natl. Acad. Sci., 106, 18447-18451, 2009. 
Hewitt, C. N., Lee, J. D., MacKenzie, A. R., Barkley, M. P., Carslaw, N., Carver, G. D., Chappell, N. A., Coe, H., Collier, C., Commane, R., Davies, F., Davison, B., DiCarlo, P., Di Marco, C. F., Dorsey, J. R., Edwards, P. M., Evans, M. J., Fowler, D., Furneaux, K. L., Gallagher, M., Guenther, A., Heard, D. E., Helfter, C., Hopkins, J., Ingham, T., Irwin, M., Jones, C., Karunaharan, A., Langford, B., Lewis, A. C., Lim, S. F., MacDonald, S. M., Mahajan, A. S., Malpass, S., McFiggans, G., Mills, G., Misztal, P., Moller, S., Monks, P. S., Nemitz, E., Nicolas-Perea, V., Oetjen, H., Oram, D. E., Palmer, P. I., Phillips, G. J., Pike, R., Plane, J. M. C., Pugh, T., Pyle, J. A., Reeves, C. E., Robinson, N. H., Stewart, D., Stone, D., Whalley, L. K., and Yin, X.: Overview: oxidant and particle photochemical processes above a south-east Asian tropical rainforest (the OP3 project): introduction, rationale, location characteristics and tools, Atmos. Chem. Phys., 10, 169-199, doi:10.5194/acp-10-169-2010, 2010.

Hofzumahaus, A., Rohrer, F., Lu, K., Bohn, B., Brauers, T., Chang, C., Fuchs, H., Holland, F., Kita, K., Kondo, Y., Li, X., Lou, S., Shao, M., Zeng, L., Wahner, A., and Zhang, Y.: Amplified Trace Gas Removal in the Troposphere, Science, 324, 17021704, 2009.

Holtslag, A. A. M., and Boville, B. A., Local versus nonlocal boundary-layer diffusion in a global climate model, J. Clim., 6, 1825-1842, 1993.

Kesselmeier, J. and Staudt, M., Biogenic Volatile Organic Compounds (VOC): An Overview on Emission, Physiology and Ecology, J. Atmos. Chem., 33, 23-38, doi:10.1023/A:1006127516791, 1999.

Hough, A. M.: The calculation of photolysis rates for use in global tropospheric modelling studies, AERE Report, 13259, At. Energy Res. Estab., Harwell, UK, 1988.

Langford, B., Misztal, P. K., Nemitz, E., Davison, B., Helfter, C., Pugh, T. A. M., MacKenzie, A. R., Lim, S. F., and Hewitt, C. N.: Fluxes and concentrations of volatile organic compounds from a South-East Asian tropical rainforest, Atmos. Chem. Phys., 10, 8391-8412, doi:10.5194/acp-10-8391-2010, 2010.

Lathiére, J., Hauglustaine, D. A., Friend, A. D., De NobletDucoudré, N., Viovy, N., and Folberth, G. A.: Impact of climate variability and land use changes on global biogenic volatile organic compound emissions, Atmos. Chem. Phys., 6, 2129-2146, doi:10.5194/acp-6-2129-2006, 2006.

Law, K. S. and Pyle, J. A., Modeling trace gas budgets in the troposphere: 1. Ozone and odd nitrogen, J. Geophys. Res., 98, 1837718400, doi:10.1029/93JD01479, 1993.

Lelieveld, J., Butler, T. M., Crowley, J. N., Dillon, T. J., Fischer, H., Ganzeveld, L., Harder, H., Lawrence, M. G., Martinez, M., Taraborrelli, D. and Williams, J., Atmospheric oxidation capacity sustained by a tropical forest, Nature, 452, 737-740, doi:10.1038/nature06870, 2008.

Liu, S., Trainer, M., Fehsenfeld, F., Parrish, D., Williams, E., Fahey, D., Hübler, G., and Murphy, P.: Ozone production in the rural troposphere and the implications for regional and global ozone distributions, J. Geophys. Res., 92, 4191-4207, doi:10.1029/JD092iD04p04191, 1987.

Long, S. P., Ainsworth, E. A., Leakey, A. D. B., and Morgan, P. B.: Global food insecurity. Treatment of major food crops with elevated carbon dioxide or ozone under large-scale fully open-air conditions suggests recent models may have over-estimated future yields, Phil. Trans. Royal Society B - Biol. Sci., 360, 2011
2020, doi:10.1098/rstb.2005.1749, 2005.

MacKenzie, A. R., Langford, B., Pugh, T. A. M., Robinson, N., Misztal, P. K., Heard, D. E., Lee, J. D., Lewis, A. C., Jones, C. E., Hopkins, J. R., Philips, G., Monks, P. S., Karunaharan, A., Hornsby, K. E., Nicolas-Perea, V., Coe, H., Whalley, L. K., Edwards, P. M., Evans, M. J., Stone, D., Ingham, T., Commane, R., Furneaux, K. L., McQuaid, J., Nemitz, E, Seng, Y. K., Fowler, D., Pyle, J. A., and Hewitt, C. N.: The atmospheric chemistry of trace gases and particulate matter emitted by different land uses in Borneo, Phil. Trans. R. Soc. B, 366, 3177-3195, doi:10.1098/rstb.2011.0053, 2011.

Malaysian Palm Oil Association (MPOA), Annual Report 2008, http://www.mpoa.org.my/v2/index.php, 2008.

Misztal, P. K., Owen, S. M., Guenther, A. B., Rasmussen, R., Geron, C., Harley, P., Phillips, J. G., Ryan, A., Edwards, D. P., Hewitt, C. N., Nemitz, E., Siong, J., Heal, M. R., and Cape, J. N.: Large estragole fluxes from oil palms in Borneo, Atmos. Chem. Phys., 10, 4343-4358, doi:10.5194/acp-10-4343-2010, 2010.

Misztal, P. K., Nemitz, E., Langford, B., Di Marco, C. F., Phillips, G. J., Hewitt, C. N., MacKenzie, A. R., Owen, S. M., Fowler, D., Heal, M. R., and Cape, J. N.: Direct ecosystem fluxes of volatile organic compounds from oil palms in South-East Asia, Atmos. Chem. Phys., 11, 8995-9017, doi:10.5194/acp-11-89952011, 2011.

Morgenstern, O., Braesicke, P., Hurwitz, M. M., O’Connor, F. M., Bushell, A. C., Johnson, C. E., and Pyle, J. A.: The World Avoided by the Montreal Protocol, Geophys. Res. Lett., 35, L16811, doi:10.1029/2008GL034590, 2008.

NCAR: Operating instructions for the MEGAN model, National Center for Atmospheric Research, Available on-line at: http: //cdp.ucar.edu/, 2007.

Pattenden, S., Armstrong, B., Milojevic, A., Heal, M. R., Chalabi, Z., Doherty, R., Barratt, B., Kovats, R. S., and Wilkinson, P.: Ozone, heat and mortality: acute effects in 15 British conurbations, Occupat. Environ. Med., 67, 699-707, doi:10.1136/oem.2009.051714, 2010.

Paulot. F, Crounse, J. D., Kjaergaard, H. G., Kroll, J. H., Seinfeld, J. H., and Wennberg, P. O.: Isoprene photooxidation: new insights into the production of acids and organic nitrates, Atmos. Chem. Phys., 9, 1503-1520, 2009, http://www.atmos-chem-phys.net/9/1503/2009/.

Peeters, J., Nguyen, T. L., and Vereecken, L.: $\mathrm{HO}_{\mathrm{x}}$ radical regeneration in the oxidation of isoprene, Phys. Chem. Chem. Phys., 11, 5935-5939, doi:10.1039/B908511D, 2009.

Pike, R. C., Lee, J. D., Young, P. J., Carver, G. D., Yang, X., Warwick, N., Moller, S., Misztal, P., Langford, B., Stewart, D., Reeves, C. E., Hewitt, C. N., and Pyle, J. A.: $\mathrm{NO}_{\mathrm{x}}$ and $\mathrm{O}_{3}$ above a tropical rainforest: an analysis with a global and box model, Atmos. Chem. Phys., 10, 10607-10620, doi:10.5194/acp10-10607-2010, 2010.

Pöschl, U., von Kuhlmann, R., Poisson, N. and Crutzen, P. J.: Development and intercomparison of condensed isoprene oxidation mechanisms for global atmospheric modelling, J. Atmos. Chem., 37, 29-52, 2000.

Prather, M. J., Numerical advection by conservation of second-order moments, J. Geophys. Res., 91, 6671-6681, doi:10.1029/JD091iD06p06671, 1986.

Pugh, T. A. M., MacKenzie, A. R., Hewitt, C. N., Langford, B., Edwards, P. M., Furneaux, K. L., Heard, D. E., Hopkins, J. R., 
Jones, C. E., Karunaharan, A., Lee, J., Mills, G., Misztal, P., Moller, S., Monks, P. S., and Whalley, L. K.: Simulating atmospheric composition over a South-East Asian tropical rainforest: performance of a chemistry box model, Atmos. Chem. Phys., 10, 279-298, doi:10.5194/acp-10-279-2010, 2010.

Pugh, T. A. M., MacKenzie, A. R., Langford, B., Nemitz, E., Misztal, P. K., and Hewitt, C. N.: The influence of small-scale variations in isoprene concentrations on atmospheric chemistry over a tropical rainforest, Atmos. Chem. Phys., 11, 4121-4134, doi:10.5194/acp-11-4121-2011, 2011.

Reijnders, L. and Huijbregts, M. A. J.: Palm oil and the emission of carbon-based greenhouse gases, J. Clean. Prod., 16, 477-482, 2008.

Sillman, S.: The use of $\mathrm{NO}_{y}, \mathrm{H}_{2} \mathrm{O}_{2}$ and $\mathrm{HNO}_{3}$ as indicators for ozone- $\mathrm{NO}_{\mathrm{x}}$-hydrocarbon sensitivity in urban locations, J. Geophys. Res., 100, 14175-14188, doi:10.1029/94JD02953, 1995.

Spracklen, D. V., Arnold, S. R., and Taylor, C. M.: Observations of increased tropical rainfall preceded by air passage over forests, Nature, 489, 282-285, doi:10.1038/nature11390, 2012.

Stevenson, D. S., Dentener, F. J., Schultz, M. G., Ellingsen, K., van Noije, T. P. C., Wild, O., Zeng, G., Amann, M., Atherton, C. S., Bell, N., Bergmann, D. J., Bey, I., Butler, T., Cofala, J., Collins, W. J., Derwent, R. G., Doherty, R. M., Drevet, J., Eskes, H. J., Fiore, A. M., Gauss, M., Hauglustaine, D. A., Horowitz, L. W., Isaksen, I. S. A., Krol, M. C., Lamarque, J. F., Lawrence, M. G., Montanaro, V., Muller, J. F., Pitari, G., Prather, M. J., Pyle, J. A., Rast, S., Rodriguez, J. M., Sanderson, M. G., Savage, N. H., Shindell, D. T., Strahan, S. E., Sudo, and K., Szopa: Multimodel ensemble simulations of present-day and near-future tropospheric ozone, J. Geophys. Res., 111, D08301, doi:10.1029/2005JD006338, 2006.

Stickler, C., Coe, M., Nepstad, D., Fiske, G., and Lefebvre, P.: Readiness for REDD: a preliminary global assessment of tropical forested land suitability for agriculture, Woods Hole Research Center Report, 2007.

Stone, D., Evans, M. J., Edwards, P. M., Commane, R., Ingham, T., Rickard, A. R., Brookes, D. M., Hopkins, J., Leigh, R. J., Lewis, A. C., Monks, P. S., Oram, D., Reeves, C. E., Stewart, D., and Heard, D. E.: Isoprene oxidation mechanisms: measurements and modelling of $\mathrm{OH}$ and $\mathrm{HO}_{2}$ over a South-East Asian tropical rainforest during the OP3 field campaign, Atmos. Chem. Phys., 11, 6749-6771, doi:10.5194/acp-11-6749-2011, 2011.
Thoenes, P.: Biofuels and Commodity Markets - palm oil focus, Technical report, Commodities and Trade Division, United Nations Food and Agriculture Organization, Rome, 2007.

Tiedke, M.: A comprehensive mass flux scheme for cumulus parameterization in large-scale models, Mon. Weather Rev., 117, 1779-1800, 1989.

Wang, K. Y., Pyle, J. A., and Bridgeman, C., Implementation of a convective atmospheric boundary layer scheme in a tropospheric chemistry transport model, J. Geophys. Res., 104, 23729-23745, 1999.

Whalley, L. K., Edwards, P. M., Furneaux, K. L., Goddard, A., Ingham, T., Evans, M. J., Stone, D., Hopkins, J. R., Jones, C. E., Karunaharan, A., Lee, J. D., Lewis, A. C., Monks, P. S., Moller, S. J., and Heard, D. E.: Quantifying the magnitude of a missing hydroxyl radical source in a tropical rainforest, Atmos. Chem. and Phys., 11, 7223-7233, doi:10.5194/acp-117223-2011, 2011.

Yan, X., Akimoto, H., and Ohara, T.: Estimation of nitrous oxide, nitric oxide and ammonia emissions from croplands in East, Southeast and South Asia, Global Change Biol., 9, 1080-1096, doi:10.1046/j.1365-2486.2003.00649, 2003.

Young, P. J., Arneth, A., Schurgers, G., Zeng, G., and Pyle, J. A.: The $\mathrm{CO}_{2}$ inhibition of terrestrial isoprene emission significantly affects future ozone projections, Atmos. Chem. Phys., 9, 27932803, doi:10.5194/acp-9-2793-2009, 2009.

Zeng, G., Morgenstern, O., Braesicke, P., and Pyle, J. A.: Impact of stratospheric ozone recovery on tropospheric ozone and its budget, Geophys. Res. Lett., 37, L09805, doi:10.1029/2010GL042812, 2010. 